Received 24.04.2017

Reviewed 19.12.2017

Accepted 18.01.2018

A - study design

B - data collection

C - statistical analysis

D - data interpretation

$\mathbf{E}$ - manuscript preparation

F - literature search

\section{Characterization of the Hammamet basin aquifer (North-East of Algeria) through geochemical and geostructural methods and analysis}

Fatha CHELIH $^{1) A B C D}$, Chemseddine FEHDI ${ }^{2) A D E F} \bowtie$, Shuhaib KHAN ${ }^{3) D E}$

\footnotetext{
${ }^{1)}$ University of Larbi Tebessi, Department of Geology, Laboratory of Water and Environment; e-mail: fatha_geo@yahoo.fr

${ }^{2)}$ University of Larbi Tebessi, Department of Earth and Universe Sciences, Route de Constantine 12002, Tebessa, Algeria; e-mail: fehdi@yahoo.fr

${ }^{3)}$ University of Houston, Department of Earth and Atmospheric Sciences, Houston, TX 77204, USA; e-mail: sdkhan@uh.edu
}

For citation: Chelih F., Fehdi C., Khan S. 2018. Characterization of the Hammamet basin aquifer (North-East of Algeria) through geochemical and geostructural methods and analysis. Journal of Water and Land Development. No. 37 p. 39-48. DOI: 10.2478/jwld-2018-0023.

\begin{abstract}
Morphostructural, hydrogeological and hydrochemical approaches were applied to Hammamet plain and its surrounding mountains in the eastern part of Algeria to characterize the groundwater system and its potential for exploitation. The Essen and Troubia Mountains form the natural boundaries of Hammamet plain. The objective of this study is to utilize remote sensing techniques combined with structural analysis, hydrogeology and hydrogeochemistry to identify the potential fracture zones for groundwater in the strongly fractured and karstified deep aquifers. The delineated zones of potential groundwater resources are verified by detailed hydrogeological field surveys.

From a hydrogeological point of view, these two mountains, constitute a unit limited by faults oriented ENE-WSW, NNW-SSE and NNE-SSW. Specifically, fractures of the latter two directions influence the compartmentalization and the hydrogeological functioning of this unit. According to the degree of fracturing and/or karstification, two basic types of aquiferous behaviour have been distinguished: fissured aquifer (Essen Mountain and Troubia Mountain), and porous aquifer (Hammamet plain).

The study of the hydrochemical characteristics of groundwater samples shows that the majority of samples are mainly of $\mathrm{HCO}_{3}{ }^{-}$and $\mathrm{Ca}^{2+}$ water type. The ionic speciation and mineral dissolution/precipitation was calculated with the PHREEQC software. The chemical composition of the water is influenced by the dissolution and/or precipitation processes during the water-rock interaction and by the cationic exchange reactions between groundwater and alluvial sediments. The high content of $\mathrm{CO}_{2}$ in the water samples suggests that they circulate in a geochemical open system. The isotopic analysis of some groundwater samples shows a similarity with the meteoric waters, which reflect their short residence time and a low evaporation of the infiltrated water.
\end{abstract}

Key words: Algeria, aquifer, Hammamet plain, hydrogeology, isotopes, remote sensing

\section{INTRODUCTION}

Fractures play an important role in groundwater resources and contaminant hydrogeology. Fractures can enhance or reduce fluid flow and form conduits or barriers to groundwater flow [CAINE, FOSTER 1999; HEYNEKAMP et al. 1999]. Fractures are even more significant for groundwater flow in fault zones. Fractures control whether the fault core will act as a conduit, barrier, or a combined conduit-barrier system. This work studies the role and influence of different types of lineaments on the groundwater in the semiarid Hammamet plain of northeastern Algeria. 


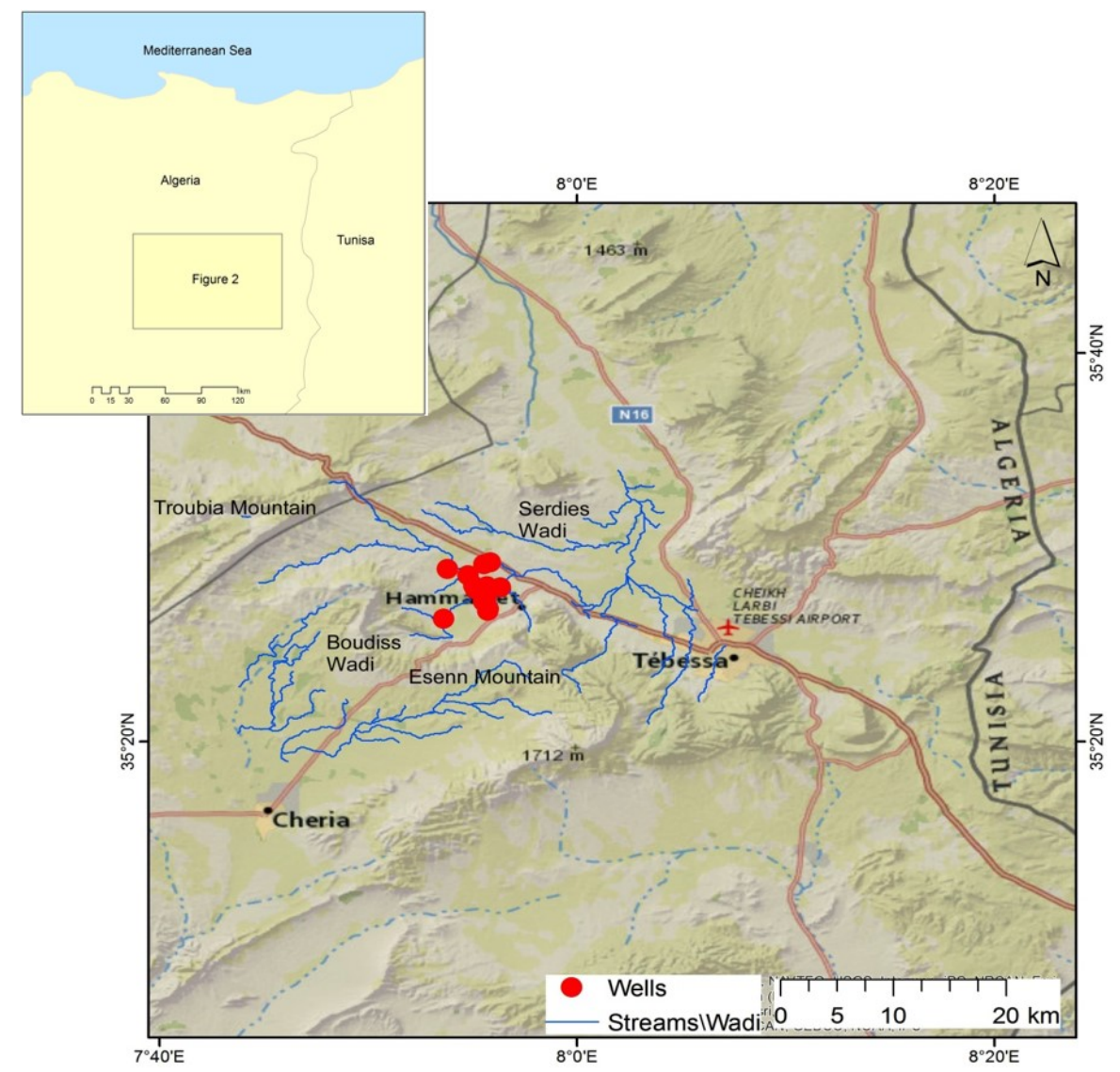

Fig. 1. Map showing location of study area and groundwater wells; source: own elaboration based on ESRI data

The study area extends from Troubia Mountain in the North-West, to Essen Mountain to the South (Fig. 1). There are several aquifers in this area (Maastrichtian and Plio-Quaternary Formations), the more important one is the Plio-Quaternary. This aquifer consists of alluvial sediments, gravels, silts, and lacustrine limestone, constituting an unconfined aquifer. This is the main aquifer that supplies drinking water to the local population. Overexploitation of this aquifer has caused degradation of the water quality.

Annual precipitation in this area ranges between 200 and $600 \mathrm{~mm}$, and as such the area is considered semi-arid. In summer, temperature can rise up to $45^{\circ} \mathrm{C}$. This situation of dryness accentuates the drawdown of water resources especially during the last decade, as the replenishment of this aquifer is very low. From 2003 to 2014 the annual precipitation varied from $200 \mathrm{~mm}$ to $600 \mathrm{~mm}$ [DERIAS, TOUBAL 2010; DJABRI 1987; FEHDI et al. 2008; ROUABHIA et al. 2009] (Fig. 2).

In this study, remote sensing data are used for mapping geology and faults, as well for extraction of fractures. Fractures are integrated with hydrological and hydrogeological data to delineate, zones of potential groundwater resources. In addition, chemical processes that are responsible for the groundwater chemistry are identified. The reconstruction of the origin and recharge mechanisms of groundwater is analysed using isotopic data.

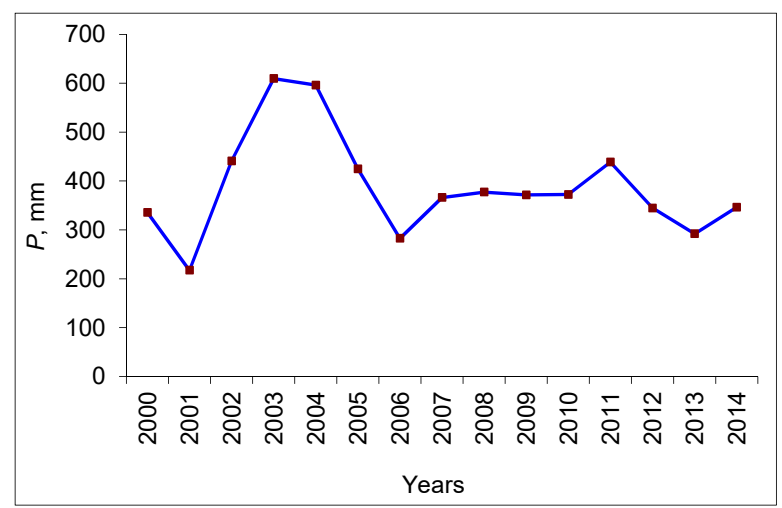

Fig. 2. Annual variation of precipitation $(P)$ in the study area (2000-2014); source: own study

\section{GEOLOGICAL}

AND HYDROGEOLOGICAL SETTING

Hammamet area is a subsidence basin, which was formed during the end of Luthitien. It is a part of a narrow trough, which forms a small portion of the great Mio-Plio-Quaternary tectonic depression of Tebessa-Morsott [FEHDI et al. 2008]. The basin is entirely filled by alluvial sediments. The bedrock consists of Cenomanian marly rocks and Cretaceous marly Turonian rocks.

The Plio-Quaternary and Quaternary terrains occupy the central part; these formations consist of 

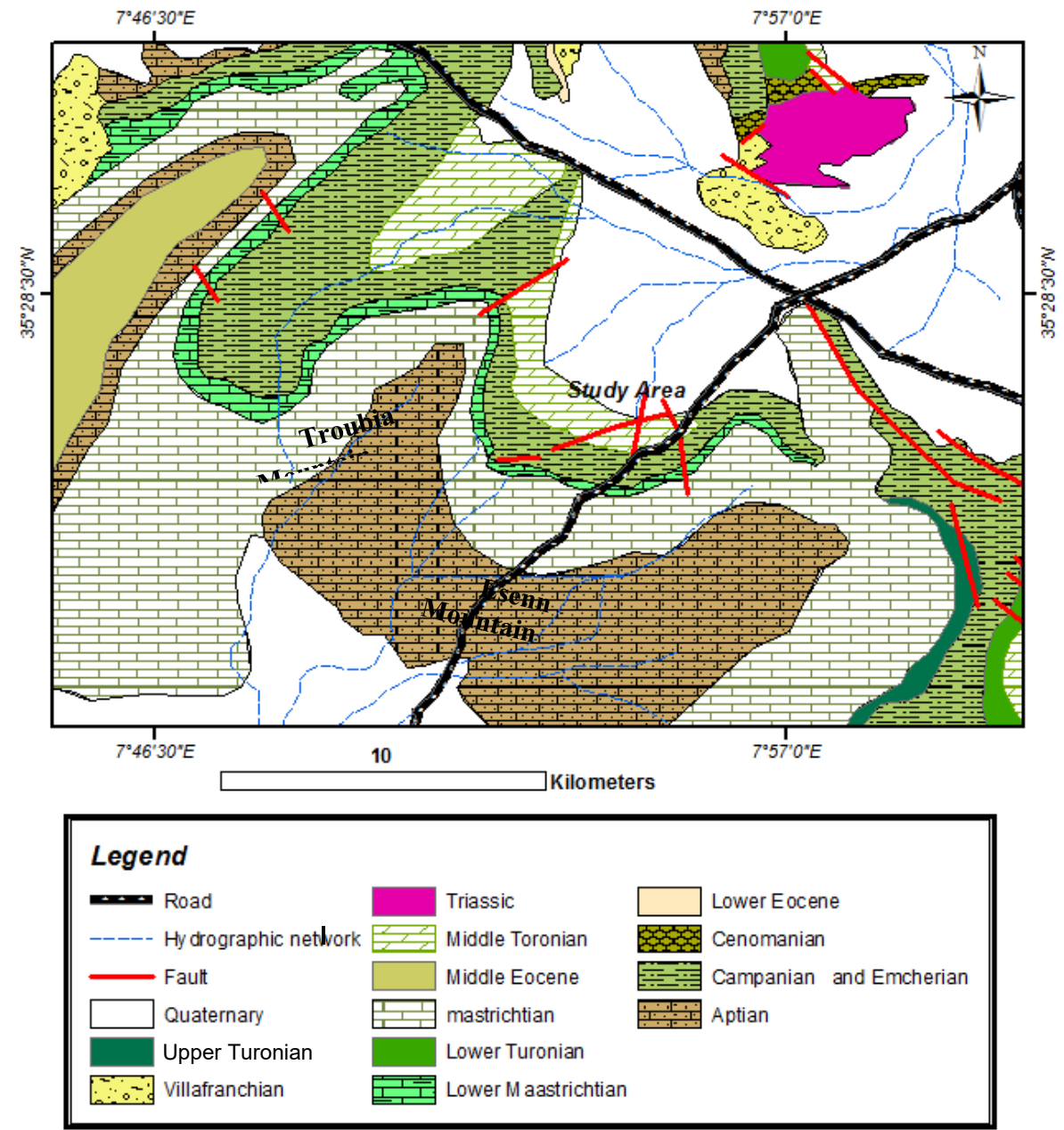

Fig. 3. Geological map of the study area complied form interpretation of satellite images and previous work; source: CHELIH [2012]

actual and recent alluvial deposits, conglomerates, gravels, sandstones, etc. Analysis of the hydrostratigraphic column of the studied area suggests the presence of two aquifers including a formation of PlioQuaternary age [DJABRI 1987]. This large alluvial aquifer occupies the major part of the tectonic depression, limited in the North and South by two large faults of W-E orientation (Fig. 3). It is composed of diverse deposits such as alluvial fans, silts, calcareous crust, conglomerates, and gravels.

This aquifer plays an important role in the drinking water supply for the local population, where it undergoes a strong usage, which generates an anthropogenic pollution.

Different wells have been drilled into the alluvial aquifer, supplying water mainly for irrigation, the groundwater levels are approximately 20 to $30 \mathrm{~m}$ below ground surface. Average water level fluctuations are up to $1.5 \mathrm{~m}$ between dry and wet seasons. The general direction of groundwater flow is from east to west. Average permeability in the sandy levels is around $10^{-3} \mathrm{~m} \cdot \mathrm{day}^{-1}$ [DJABRI 1987]. The aquifer is mainly recharged by precipitation at Djbel Troubia and Djbel Es Senn, at some places wadies may recharge or drain this aquifer.

\section{MATERIAL AND METHODS}

\section{REMOTE SENSING DATA}

For this work, published geological maps were scanned, imported into ArcGIS 10.4.1 and georeferenced to the UTM/WGS84 projection system. This study used multispectral, Landsat 8, Operational Land Imager (OLI) satellite data. The OLI sensor data have refined Landsat heritage bands with an improved signal-to-noise ratio. One image of Landsat 8 data for path 193 and row 35 was used in this study. This data were acquired on August 2, 2016. The OLI data were distributed as geometrically corrected and radiometrically calibrated 16-bit images for each band. The calibrated data were converted to at-sensor radiance using specified Landsat 8 gain and offset values in the metadata. The resulting reflectance data were used to create false colour composite images, that are the simplest and most commonly used methods for multispectral satellite data such as Landsat and ASTER [KHAN, GLENN 2006] Shuttle Radar Topography Mission (SRTM) version 4 [http://srtm.csi.cgiar.org/] digital elevation model (DEM) data were also used for extracting lineament. 
The lineament extraction and identification were carried out in three steps. First, faults were manually traced and lineaments were extracted from hillshade images generated from SRTM DEM. Manmade features such as roads, ditches and other linear structures were excluded from the interpreted lineaments. Next, the extracted lineaments were overlain on satellite images for verification and finally, some of the extracted lineaments were confirmed in the field.

\section{HYDROGEOLOGY}

Measurements of groundwater levels is important for several reasons, including a hydrograph plot, and the construction of a piezometric map that is necessary to determine the aquifer extension and direction of flow in the aquifer. In the study area 14 wells that are distributed in the plain (Plio-Quaternary) of Hammamet were used for water level measurement. The depths of the groundwater level varied between 50 and $150 \mathrm{~m}$ (ANRH/National Hydraulic Resources Agency Tebessa, Algeria).

Groundwater samples were also collected for geochemical analysis at different depths from these 14 production wells penetrating the shallow aquifers. Field surveys and chemical analyses were performed in June 2014. Portable equipment was used to obtain in situ readings of temperature, $\mathrm{pH}$, and electrical conductivity $(E C)$. At the same time, samples of nonacidified water in $500 \mathrm{ml}$ polyethylene bottles were taken. The field campaigns took 3 or 4 days; during this period, the samples were kept at a low temperature in a portable refrigerator. The $\mathrm{HCO}_{3}{ }^{-}$content was determined as total alkalinity, by titration with $\mathrm{HCl}^{-}$ $0.05 \mathrm{~N}$ and methyl orange as indicator. The cations were analysed by atomic absorption spectrometry $(\mathrm{Ca}$ and $\mathrm{Mg}$ ) and by emission spectrometry ( $\mathrm{Na}$ and $\mathrm{K}$ ). A visible light spectrophotometer was used to analyse $\mathrm{SO}_{4}$ by turbidimetry and the $\mathrm{SiO}_{2}$, by colorimetry. The concentrations of $\mathrm{Cl}^{-}$ions were determined by argentometric titration, using $\mathrm{AgNO}_{3} 0.01 \mathrm{~N}$ and $5 \%$ $\mathrm{K}_{2} \mathrm{CrO}_{4}$ as indicator. The hydrochemical calculations were performed using the DIAGRAMME program [SIMLER 2004], and PHREEQC [PARKHURST, APELLO 1999]. The saturation indices of calcite, dolomite, aragonite and gypsum, and the partial equilibrium pressure of $\mathrm{CO}_{2}$ were determined. Saturation indices express the extent of chemical equilibrium between water and mineral phases in the matrix of the aquifers and can be regarded as a measure of dissolution and/or precipitation processes relating to the waterrock interaction [DREVER 1988].

The degree of saturation can be evaluated according to the following equation:

$$
S I=\log \left(K_{\mathrm{IAP}} / K s p\right)
$$

Where: $K_{\mathrm{IAP}}=$ ionic activity product of the ions, $K s p$ $=$ solubility product of the mineral, $S I=$ saturation index.
If $S I<0$, the water is undersaturated with respect to a certain mineral, which means that the water is still able to dissolve that specific mineral;

If $S I>0$, the water is oversaturated with respect to that mineral and the mineral will precipitate;

If $S I=0$, the water is in equilibrium.

Fourteen samples were analysed for oxygen and hydrogen isotopes using a mass spectrometer at the University of Montpellier, France. For oxygen isotopes $\left(\delta^{18} \mathrm{O}\right)$, one microliter of water was heated to high temperature to obtain vapours that were injected into the mass spectrometer for analysis. The same technique was undertaken for hydrogen isotopes $\left(\delta^{2} \mathrm{H}\right)$.

\section{RESULTS AND DISCUSSION}

\section{REMOTE-SENSING ANALYSIS}

Landsat 8 and SRTM DEM helped in extracting lineaments and lithology [TUMARE et al. 2014]. Analyses show that lineaments oriented in NE-SW and E-W directions are most dominant. Most of these lineaments are associated with geomorphological features and control the drainage patterns. Extracted lineaments are mainly located in the Essen Mountain and Troubia regions along the border of Hammamet plain (Fig. 4).

\section{HYDROGEOLOGY}

Piezometric measurements of fourteen wells of Plio Quaternary Formation are plotted as contours and demonstrate a convergence of flow directions towards the South-East and the West of Hammamet plain [CHELIH 2012]. The flow is diverging in the North suggesting that groundwater is generally moving in two directions: South-West to North-East and West to the East (Fig. 5).

\section{CLASSIFICATION OF THE WATER SAMPLES}

The chemical analysis of the studied samples is presented in Table 1. Water samples are classified according to their chemical composition using the Piper diagram [PIPER 1944]. This classification is based on the concentration of the four major anions bicarbonate, sulphate, chloride and nitrate and on the four major cations sodium, potassium, calcium and magnesium [BEN et al. 2016].

The Piper diagram in Figure 6 shows that the overall chemical character falls within a fresh groundwater end-member $\mathrm{CaHCO}_{3}$ water type with low salinity. The water type varies due to the influence of many factors.

Firstly, the water rock interaction of the aquifer material and secondly, the influences of human activities such as irrigation return flow [BOUSSAHA, LAIFA 2017]. The result is a rapid spatial increase in sodium, 


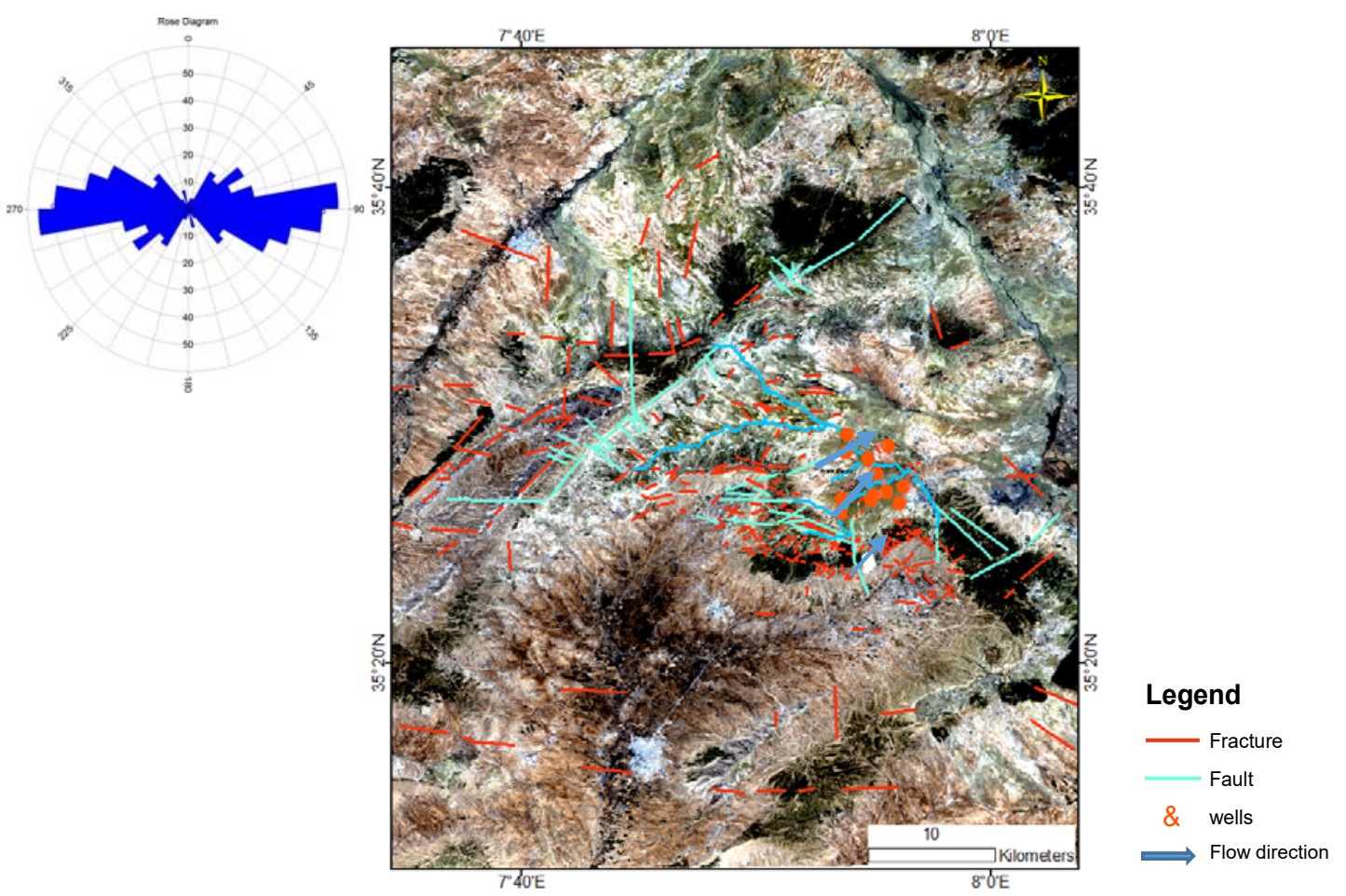

Fig. 4. Landsat 8 true colour combination, bands 3-2-1 displayed as red-green-blue;

Extracted lineaments, faults, water wells and groundwater flow direction are also shown; source: own elaboration

Fig. 5. SRTM DEM image with groundwater level contours (piezometric data) showing the flow direction of groundwater in Hammamet plain; source: own elaboration

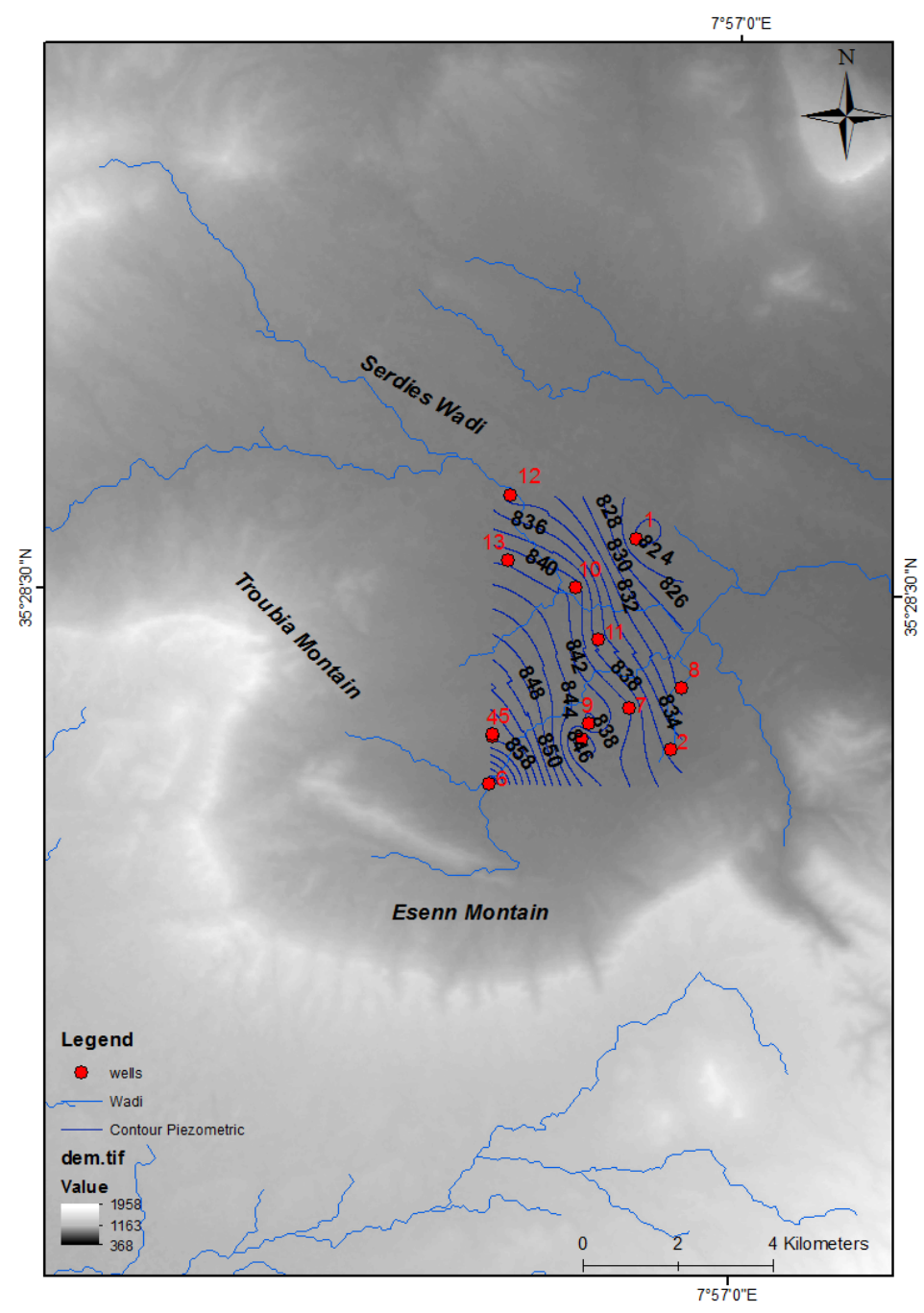


Table 1. Chemical composition of groundwater from Hammamet aquifer

\begin{tabular}{|c|c|c|c|c|c|c|c|c|c|c|c|}
\hline \multirow{2}{*}{ Wells } & \multirow{2}{*}{$\mathrm{pH}$} & \multirow{2}{*}{$\begin{array}{c}T \\
{ }^{\circ} \mathrm{C} \\
\end{array}$} & \multirow{2}{*}{$\begin{array}{c}E C \\
\mu \mathrm{S} \cdot \mathrm{cm}^{-1}\end{array}$} & \multirow{2}{*}{$\begin{array}{c}\text { Salinity } \\
\mathrm{g} \cdot \mathrm{dm}^{-3}\end{array}$} & $\mathrm{Ca}^{+}$ & $\mathrm{Mg}^{2+}$ & $\mathrm{Na}^{+}$ & $\mathrm{K}^{+}$ & $\mathrm{HCO}_{3}{ }^{+}$ & $\mathrm{Cl}^{-}$ & $\mathrm{SO}_{4}^{2-}$ \\
\hline & & & & & \multicolumn{7}{|c|}{$\mathrm{mg} \cdot \mathrm{dm}^{-3}$} \\
\hline $\mathrm{P} 1$ & 7.71 & 22.6 & 887 & 0.4 & 106.6 & 27.77 & 80.8 & 2.3 & 219.0 & 84.99 & 237.0 \\
\hline P2 & 7.86 & 21.4 & 1593 & 0.8 & 112.2 & 28.20 & 42.3 & 5.3 & 242.0 & 279.7 & 256.0 \\
\hline P3 & 7.62 & 20.4 & 877 & 0.4 & 158.0 & 29.66 & 49.0 & 6.0 & 241.0 & 139.9 & 200.9 \\
\hline $\mathrm{P} 4$ & 7.73 & 19.7 & 654 & 0.3 & 96.19 & 29.66 & 45.98 & 5.6 & 235.0 & 142.1 & 223.7 \\
\hline P5 & 7.55 & 20.2 & 777 & 0.3 & 92.12 & 32.40 & 48.6 & 5.0 & 209.1 & 27.99 & 231.0 \\
\hline P6 & 7.45 & 20.0 & 1061 & 0.3 & 78.55 & 34.03 & 64.0 & 4.0 & 226.0 & 91.99 & 223.3 \\
\hline $\mathrm{P} 7$ & 7.20 & 22.3 & 688 & 0.4 & 118.1 & 35.90 & 77.0 & 8.2 & 224.0 & 224.2 & 254.0 \\
\hline P8 & 7.36 & 22.6 & 881 & 0.4 & 88.17 & 38.89 & 57.0 & 6.3 & 248.0 & 79.99 & 217.1 \\
\hline P9 & 7.36 & 22.6 & 1364 & 0.7 & 93.78 & 54.94 & 60.2 & 7.8 & 214.3 & 214.9 & 278.2 \\
\hline $\mathrm{P} 10$ & 7.18 & 20.0 & 1770 & 0.8 & 162.1 & 55.10 & 70.2 & 5.2 & 221.0 & 244.1 & 265.6 \\
\hline P11 & 7.73 & 22.1 & 2240 & 1.3 & 224.4 & 87.52 & 50.2 & 7.1 & 305.2 & $\begin{array}{l}409.9 \\
\end{array}$ & 271.3 \\
\hline P12 & 7.30 & 22.2 & 1800 & 0.8 & 256.0 & 35.60 & 57.6 & 4.1 & 225.0 & 71.0 & 258.0 \\
\hline $\mathrm{P} 13$ & 6.80 & 22.0 & 1500 & 0.6 & 305.0 & 35.60 & 44.88 & 3.2 & 220.0 & 35.5 & 272.0 \\
\hline P14 & 6.30 & 20.0 & 2110 & 0.2 & 84.0 & 61.50 & 110.0 & 10.2 & 255.0 & 24.85 & 264.7 \\
\hline
\end{tabular}

Explanations: $T=$ temperature, $E C=$ electrical conductivity. Source: own study.

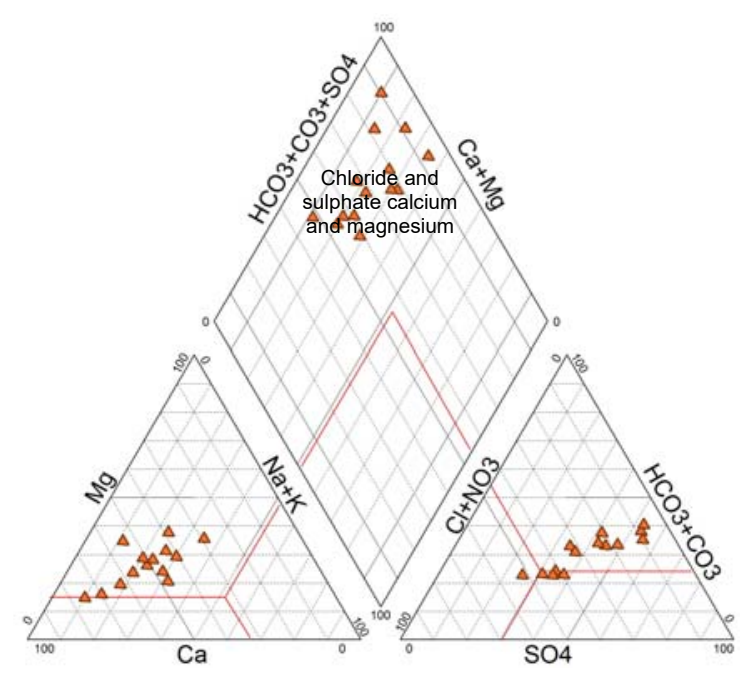

Fig. 6. Water chemistry data plotted on Piper diagram for studied samples; source: own study

sulphate and chloride concentrations in the aquifer (Tab. 1).

Interaction between groundwater and surrounding host rocks is the main process responsible for the observed chemical characteristics of groundwater in the Hammamet plain [FEHDI et al. 2008]. Evaluation of such processes requires the description of the mean mineral assemblage of the rocks in which water is located, and the identification of chemical reactions responsible for the geochemical evolution of groundwater [SALAMEH 2001]. From available studies in the literature, such reactions generally include chemical weathering of rock-forming minerals, dissolution-precipitation of secondary carbonates and ion exchange between water and clay minerals [SALAMEH 2001].

Generally, two approaches, mathematical and graphical, are used for the resolution of hydrogeochemical interactions. The mathematical approach consists of the calculation of saturation indices with respect to mineral phases, thus providing some indica- tion upon the equilibrium state between groundwater and surrounding minerals rock assemblage [ROUABHIA et al. 2009].

For this work different parameters were calculated based on the chemical analyses of the water samples including $\mathrm{pH}$-equilibrium, $\mathrm{pCO}_{2}$, ionic strength and saturation indices for calcite, aragonite, dolomite, gypsum, and anhydrite (Tab. 2).

Table 2. Saturation indices $(S I)$ of groundwater from the Hammamet aquifer

\begin{tabular}{|l|c|c|c|c|c|}
\hline Wells & $\begin{array}{c}S I \\
\text { calcite }\end{array}$ & $\begin{array}{c}S I \\
\text { dolomite }\end{array}$ & $\begin{array}{c}S I \\
\text { gypsum }\end{array}$ & $\begin{array}{c}S I \\
\text { aragonite }\end{array}$ & $\begin{array}{c}S I \\
\text { anhydrite }\end{array}$ \\
\hline P1 & 0.58 & 0.37 & -0.97 & 0.43 & -1.19 \\
\hline P2 & 0.78 & 0.76 & -0.93 & 0.63 & -1.15 \\
\hline P3 & 0.54 & 0.15 & -0.88 & 0.39 & -1.10 \\
\hline P4 & 0.34 & -0.04 & -1.03 & 0.19 & -1.25 \\
\hline P5 & -0.20 & -1.06 & 1.03 & 0.35 & -1.25 \\
\hline P6 & 0.64 & 0.66 & -1.08 & 0.49 & -1.30 \\
\hline P7 & 0.21 & -0.15 & -1.11 & 0.06 & -1.33 \\
\hline P8 & 0.10 & -0.51 & -0.92 & -0.04 & -1.14 \\
\hline P9 & 0.20 & -0.15 & -1.08 & 0.06 & -1.30 \\
\hline P10 & 0.14 & -0.15 & -0.98 & 0 & -1.20 \\
\hline P11 & 0.19 & -0.28 & -0.79 & 0.05 & -1.01 \\
\hline P12 & 0.99 & 1.37 & -0.68 & 0.84 & -0.90 \\
\hline P13 & 0.79 & 0.44 & -0.51 & 0.64 & -0.73 \\
\hline P14 & -0.86 & -2.06 & -1.04 & -1.01 & -1.26 \\
\hline
\end{tabular}

Source: own study.

The results show saturation with respect to calcite, dolomite, and aragonite but under saturation with respect to gypsum, anhydrite. The distribution of the computed $\mathrm{pCO}_{2}$ values (on a log scale) for all the groundwater samples is shown in Figure 7.

Partial $\mathrm{CO}_{2}$ pressures vary between $1013.25^{-2.8}$ and $1013.25^{-1.0} \mathrm{kPa}$, being significantly higher than that of the atmosphere $\left(1013.25^{-3.5} \mathrm{kPa}\right)$ (Fig. 7). Such elevated values suggest that the groundwater system is open to soil $\mathrm{CO}_{2}$ [BENRABAH et al. 2016]. In order to determine the source (anthropogenic or biogenic origin) of dissolved $\mathrm{CO}_{2}, \mathrm{e}^{13} \mathrm{C}$ analyses are needed. 


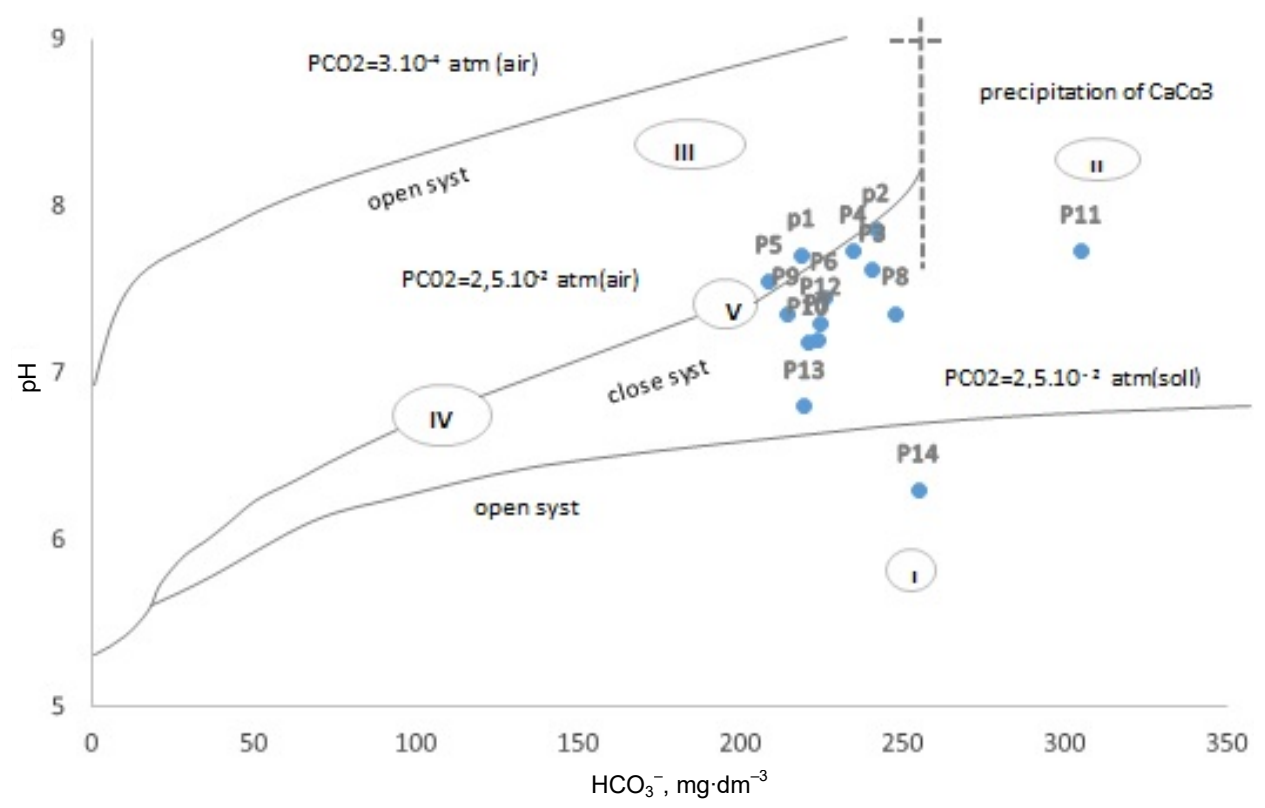

Fig. 7. Plot of $\mathrm{pH}$ versus $\mathrm{HCO}_{3}^{-}$for studied samples: I, III: open system, IV, V: close system, - - - precipitation of $\mathrm{HCO}_{3}^{-}$; source: own elaboration

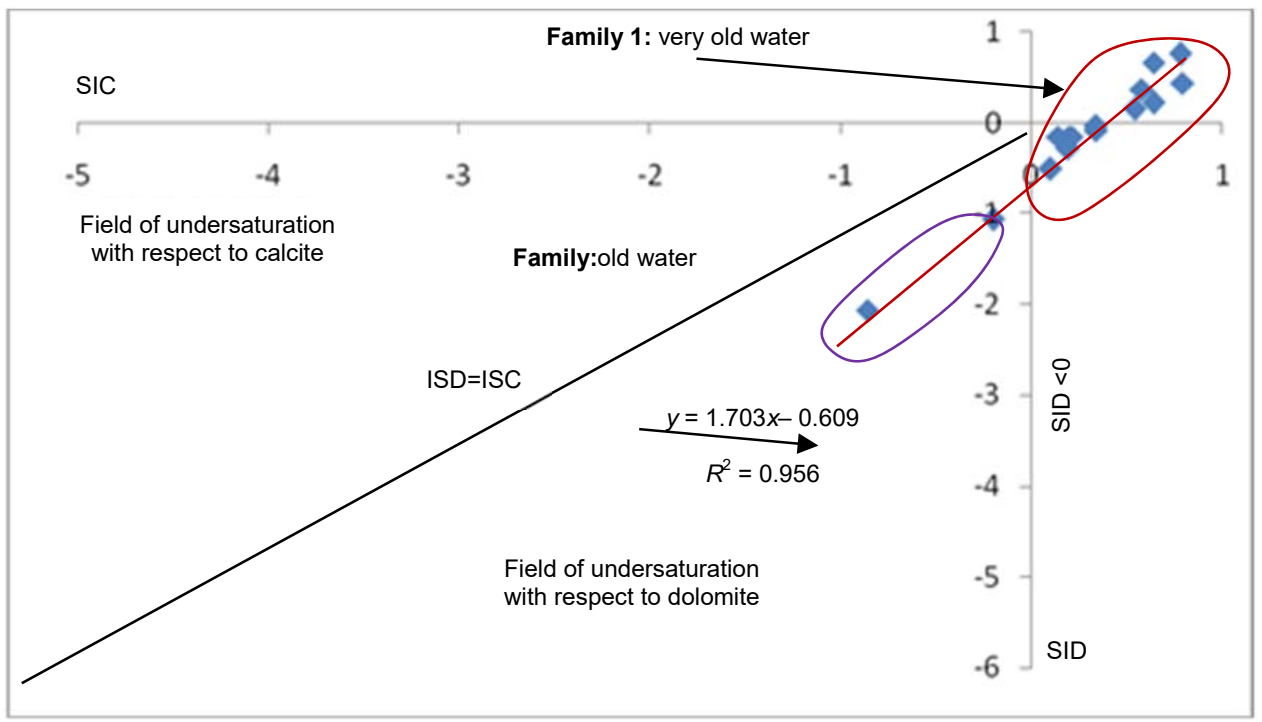

Fig. 8. Analysed samples plotted on saturation index calcite (SIC) versus saturation index dolomite (SID) diagram; source: own elaboration

Unconfined or confined aquifers also play a role in the exchange of $\mathrm{CO}_{2}$ [SAYAD et al. 2017]. In the case of our study, the acquisition of $\mathrm{CO}_{2}$ is an open system for water samples (P1, P2, P3, P4, P5, P6, P9, $\mathrm{P} 14)$, and a closed system for water samples (P7, P8, $\mathrm{P} 10, \mathrm{P} 12, \mathrm{P} 13)$. This is based on $\mathrm{pH}$ versus $\mathrm{HCO}_{3}^{-}$plot shown in Figure 7. In Figure 7, domains I and III represent hydrogeological open systems with respect to carbon. Therefore, they offer excellent circulation conditions and good infiltration of water masses in the soil (Fig. 7).

In Figure 8, saturation indices of calcite versus saturation indices of dolomite are plotted, the representative points of the water samples are aligned generally along a regression line

$(S I D=1.703 S I C-0.609)$

\section{$S I D=$ saturation index dolomite \\ $S I C=$ saturation index calcite.}

Most of the these water samples are over saturated with respect to calcite $(S I$ calcite $>0)$ and under saturated with respect to dolomite $(S I$ dolomite $<0)$ with the exception of two samples where $S I$ calcite and SI dolomite are negative. These wells are: P5 (SI calcite $=-0.20 ;$ SI dolomite $=-1.06)$ and P14 (SI calcite $=-0.86 ; S I$ dolomite $=-2.06)$.

In general the water of the study area can be divided into two groups according to the values of SI dolomite and SI calcite.

\section{Family 1 (SI dolomite $>-0.5)$}

It covers seven water samples P1, P2, P3, P4, P6, $\mathrm{P} 12$ and $\mathrm{P} 13$. The saturation indices of these samples have calcite and dolomite very close to equilibrium state. 


\section{Family 2 (IS dolomite $<-0.5$ )}

The saturation indices of these samples reflect an under saturation with respect to dolomite and an oversaturation with respect to calcite.

\section{ORIGIN AND RECHARGE MECHANISM OF GROUNDWATER}

Stable isotopes of oxygen and hydrogen in groundwater of an active hydrological cycle reflect the initial isotopic composition of the recharging rainwater. $\delta^{18} \mathrm{O}$ and $\delta^{2} \mathrm{H}$ can be used to discern a meteoric line, the slope of which is characteristic of the hydrological system [FEHDI et al. 2015].

For this work $\delta^{18} \mathrm{O}$ and $\delta^{2} \mathrm{H}$ are used to establish the local meteoric water lines, that are obtained from the Global Network for Isotopes in Precipitation database managed by the AIEA, for a period of 6 years (September 1992-December 1998) for Tunis-Carthage and Sfax meteorological stations (Tunisia).

The meteoric waterlines defined for Sfax and Tunis have been calculated using a least squares regression [CELLE-JEONATANet al. 2001]:

$$
\delta^{2} \mathrm{H}=(6.4 \pm 0.5) \delta^{18} \mathrm{O}+(5.2 \pm 1.7)
$$

Tunis $(1992-1998, n=26)$

$$
\delta^{2} \mathrm{H}=(6.7 \pm 0.3) \delta^{18} \mathrm{O}+(3.5 \pm 1.3)
$$

Sfax (1992-1998, $n=45)$

The water lines of Tunis and Sfax for the period 1992-1998 are similar and thus seem to be representative of the precipitation isotopic content in Tunisia. The comparison between the Tunisia and the Global Meteoric Water line [CRAIG 1961] shows evidence of the evaporation that affects Tunisian precipitation.

Stable isotope compositions of water collected from wells and springs are presented in Table 3. Stable isotope values were found to vary between -8.13
Table 3. Isotopic composition of groundwater from the study area

\begin{tabular}{|c|l|r|r|c|}
\hline Samples & Wells and springs & \multicolumn{1}{|c|}{$\mathrm{Z}, \mathrm{m}$} & \multicolumn{1}{c|}{$\mathrm{dO}^{18}$} & \multicolumn{1}{c|}{$\mathrm{dH}^{2}$} \\
\hline 1 & Bouakous Spring & 950 & -8.12 & -51.75 \\
\hline 2 & Wadi Bouakous & 910 & -8.13 & -51.30 \\
\hline 3 & Ammacha Spring & 1000 & -7.79 & -51.05 \\
\hline 4 & P1 & 909 & -7.96 & -47.44 \\
\hline 5 & P2 & 883 & -7.94 & -52.38 \\
\hline 6 & P3 & 985 & -7.81 & -51.60 \\
\hline 7 & P4 & 850 & -7.86 & -55.23 \\
\hline 8 & P5 & 850 & -7.86 & -49.32 \\
\hline 9 & P6 & 885 & -7.61 & -49.11 \\
\hline 10 & Gaagaa Spring & 1200 & -8.03 & -52.92 \\
\hline 11 & P7 & 840 & -7.46 & -50.41 \\
\hline 12 & P8 & 869 & -7.93 & -52.63 \\
\hline 13 & P9 & 870 & -7.40 & -48.25 \\
\hline 14 & P10 & 860 & -7.35 & -51.10 \\
\hline
\end{tabular}

Source: own study.

and -7.35 in $\mathrm{O}^{18}$ with a mean of $-7.803 \pm 0.2 \%$ o $(n=14)$ and from -55.23 to -47.43 in $\mathrm{H}^{2}$ with a mean of $-51.88 \pm 0.15 \%$ o $(n=14)$.

The $\delta^{18}$ Oand $\delta^{2} \mathrm{H}$ contents for all the investigated groundwater samples are plotted in the classical $\mathrm{O}^{18}$ $\mathrm{H}^{2}$ diagram, together with the global meteoric water line $\left(\delta^{2} \mathrm{H}=8 \delta^{18} \mathrm{O}+10\right)$, defined by CRAIG [1961] and the local meteoric water lines (Tunis and Sfax).

Figure 9 shows that nearly all of the groundwater samples are plotted close to the Tunis, Sfax Meteoric line, and GMWL, and indicate no significant isotopic modifications by evaporation, which means that the recharge of the aquifer is quite rapid, and the recharging meteoric water does not occupy the soil zone of the recharge area for a long time [BAGHDADI et al. 2013].

The similarity of $\delta^{2} \mathrm{H}$ versus $\delta^{18} \mathrm{O}$ for both wells and spring groundwater samples is not surprising in karst regions and suggests the rapid recharge (fast infiltration process) of the precipitation to the groundwater throughout highly karst carbonate at high eleva-

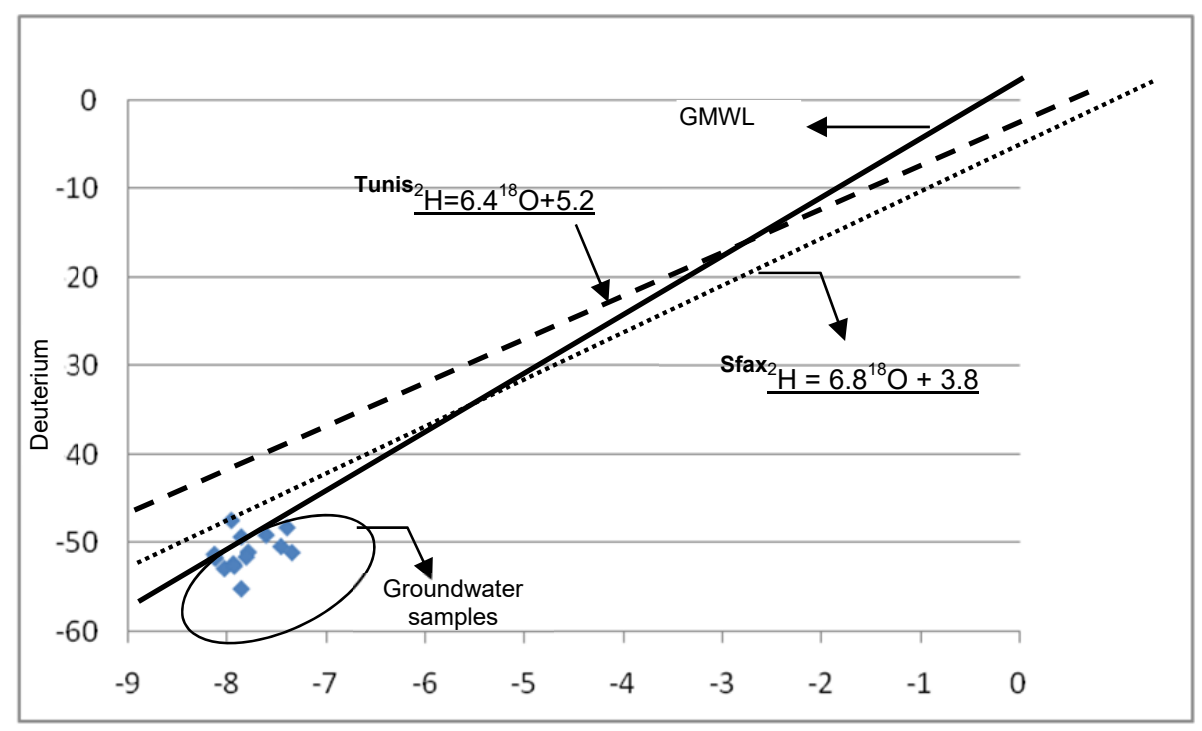

Oxygen18

Fig. 9. $\delta^{2} \mathrm{H}$ vs $\delta{ }^{18}$ Orelationship for groundwater in the study area; source: own study 


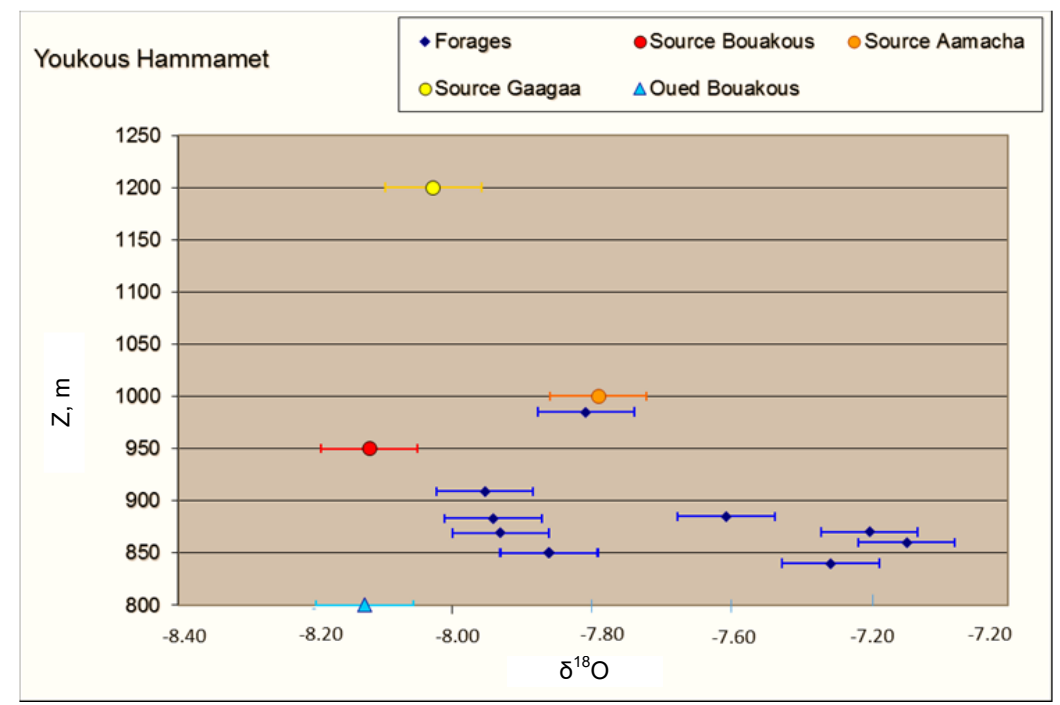

Fig. 10. Altitude $Z$ and $\delta^{18} \mathrm{O}$ relationship of the studied water samples; source: own study

tions (Fig. 10) and indicates that groundwater is of meteoric origin [ARAGUAS, DIAZ-TEIJEIRO 2005]. The deuterium excess values indicate that the study area is recharged by locally originated atmospheric water with low evaporation rates.

\section{CONCLUSIONS}

The analysis of the fractures suggest that the mountains of Essen and Troubia, which are the natural boundaries of Hammamet plain, have faults and joints of different sizes and a presence of four principal directions of fractures (NE-SW, E-W, NW-SE and $\mathrm{N}-\mathrm{S}$ ). Fractures oriented in NNW-SSE and NNE-SSW directions influence the compartmentalization and the hydrogeological functioning of geological unit.

The overall chemical character of the groundwater of the study area falls within the fresh groundwater end-member: $\mathrm{CaHCO}_{3}{ }^{-}$water type with low salinity concentrations. The chemical composition of the water is influenced by the dissolution and/or precipitation processes during the water-rock interaction and to the cationic exchange reactions between groundwater and alluvial sediments. The high content of $\mathrm{CO}_{2}$ in the waters samples suggests that water circulate in a geochemical open system.

All the underground flow systems are fed by meteoric water. The studied water samples collected from springs and wells are from recharge at the highest elevations.

\section{REFERENCES}

Araguas L.J., Diaz TeiJeiro M.F. 2005. Isotope composition of precipitation and water vapour in the Iberian Peninsula: first results of the Spanish network of isotopes in precipitation. In: International atomic energy agency - isotopic composition of precipitation in the Mediterranean Basin in relation to air circulation patterns and climate. Vienna. IAEA-TECDOC-1453 p. $173-190$.
BAghdAdi M., MEdDAh R., RAIS J., NADEM S., AfdAli M. 2013. Evaluation of water quality in open channels flowing through Beni-Mellal City (Morocco). Journal of Water and Land Development. No. 19 p. 5-9.

Benrabah S., Attoui B., Hannouche M. 2016. Characterization of groundwater quality destined for drinking water supply of Khenchela City (eastern Algeria). Journal of Water and Land Development. No. 30 p. 13-20. DOI 10.1515/jwld-2016-0016.

BousSAHA S., LAIFA A. 2017. Wadi Bounamoussa's waters quality in the north-east of Algeria: Statistical treatment of some physical and chemical parameters. Journal of Water and Land Development. No. 34 p. 77-83. DOI 10.1515/jwld-2017-0040.

CAINE J.S., Forster C.B. 1999. Fault zone architecture and fluid flow insights from field data and numerical modelling. American Geophysical Union. Geophysical Monogram Series. Vol. 113 p. 9-7. DOI 10.1029/GM113p 0101.

Celle-Jeonatan H., Zouar K., Travi Y., Daoued A. 2001. Caractérisation isotopique des pluies en Tunisie. Essai de typologie dans la région de Sfax [Isotopic characterization of precipitations in Tunisia: Typology test in the region of Sfax]. Sciences de la Terre et des planètes / Earth and Planetary Sciences. Vol. 333 p. $625-631$.

CGIARCSI undated. Shuttle Radar Topography Mission (SRTM), version 4 [online]. [Access 2.08.2016]. Available at: http://srtm.csi.cgiar.org/

Chelih F. 2012. Role and characteristics of the Turonian limestones in the alimentation of Plio Quaternary aquifer. Hammamet Tebessa. MSc Thesis. Tebessa University.

CrAIG H. 1961. Standard for representing concentrations of deuterium and oxygen-18 in natural waters. Science. Vol. 133 p. 1833-1834.

Derias T., Toubal A.C. 2010. Hydrodynamic characterization of a heterogeneous aquifer system or semi-arid climate. Example of the plain of Tebessa. Bulletin of the Geological Service of Algeria. Vol. 21(3) p. 361-372.

DJABRI L. 1987. Contribution to the hydrogeological study of the subsidence plain of Tebessa NE Algeria. Attempt of modeling. PhD Thesis. University of Franche Comté, France. 
DREVER J.I. 1988. The geochemistry of natural waters. $2^{\text {nd }}$ ed. Englewood Cliffs. Prentice-Hall. ISBN 0133513963 pp. 437.

FehDi C., Belfar D., BAAli F. 2015. Characterization of the main karst aquifers of the Tezbent Plateau, Tebessa Region, Northeast of Algeria, based on hydrogeochemical and isotopic data. Environmental Earth Sciences. Vol. 74. Iss. 1 p. 241-250. DOI 10.1007/s12665-0154480-x.

Fehdi C., Rouabhia A., BaAli F. 2008. The hydorogeochemical characterization of Morsott-El Aouinet aquifer, Northeastern Algeria. Environmental Geology. Vol. 58 p. 1611. DOI 10.1007/s00254-008-1667-4.

HeyneKamp M.R., Goodwin L.B., Mozley P.S., HaneBERG W.C. 1999. Controls on fault-zone architecture in poorly lithified sediments, Rio Grande Rift, New Mexico: Implications for fault-zone permeability and fluid flow, in faults and subsurface fluid flow in the Shallow Crust. In: Faults and subsurface fluid flow in the shallow crust. Eds. W.C. Haneberg, P.S. Mozley, J. Casey Moore, L.B. Goodwin. Geophysical Monograph Series. Vol. 113 p. 27-51.

KHAN S.D., GLENN N. 2006. New strike slip faults and litho-units mapped in Chitral (N. Pakistan) using field and ASTER data yield regionally significant results. International Journal of Remote Sensing. Vol. 27. Iss. 2 p. 4495-4512.

PARKHURST D.L., APPELO C.A.J. 1999. User's guide to PHREEQC (version 2) - A computer program for spe- ciation, batch-reaction, one-dimensional transport, and inverse geochemical calculations. U.S. Geological Survey Water-Resources Investigations Report 99-4259 pp. 312.

PIPER A.M. 1944. A graphic procedure in the geochemical interpretation of water-analyses. Eos, Transactions, American Geophysical Union. Vol. 25 p. 914-928.

Rouabhia A.E.K., BaAli F., FeHDi C. 2009. Impact of agricultural activity and lithology on groundwater quality in the Merdja area, Tebessa, Algeria. Arab Journal of Geosciences. Vol. 3(3) p. 307-318. DOI 10.1007/ 12517-009-0087-4.

SALAMEH E. 2001. Sources of water salinities in the Jordan Valley Area/Jordan. Acta Hydrochimica et Hydrobiologica. Vol. 29 p. 329-362.

SAyad L., DJabri L., Bouhsina S., Bertrand C., Hani A., Chaffai H. 2017. Hydrochemical study of DreanAnnaba aquifer system (NE Algeria). Journal of Water and Land Development. No. 34 p. 260-263. DOI 10.1515/jwld-2017-0061.

SIMLER R. 2007. Hydrochemistry multilanguage free distribution software. Version 4. Hydrogeology Laboratory of Avignon. Version 2.

Tumare J., Jana S.K., Pal D.K. 2014. Application of remote sensing and GIS for ground water potential zone investigation in Bulolo-Wau Surrounding Gold Mine, Morobe Province, Papua New Guinea. International Journal of Geoinformatics. Vol. 10. Iss. 4 p. 45-57.

\section{Fatha CHELIH, Chemseddine FEHDI, Shuhaib KHAN}

\section{Charakterystyka poziomu wodonośnego w basenie Hammamet (północnowschodnia Algieria) metodami i analizami geochemiczną oraz geostrukturalną}

\section{STRESZCZENIE}

Celem scharakteryzowania systemu wód podziemnych oraz możliwości eksploatacji tych wód zastosowano metody morfologiczne, hydrogeologiczne i hydrochemiczne na równinie Hammamet i otaczających ją górach we wschodniej części Algierii. Góry Essen i Troubia tworzą naturalną granicę równiny Hammamet. Przedmiotem badań była identyfikacja możliwych stref szczelin w silnie spękanym i głębokim, krasowym poziomie wodonośnym z zastosowaniem technik teledetekcji w połączeniu $\mathrm{z}$ analizą strukturalną, hydrogeologią i hydrogeochemią. Wytyczone strefy potencjalnych zasobów wód gruntowych weryfikowano w szczegółowych hydrogeologicznych badaniach terenowych.

$\mathrm{Z}$ hydrogeologicznego punktu widzenia wymienione góry stanowią jednostkę ograniczona przez uskoki ułożone wzdłuż linii ENE-WSW, NNW-SSE i NNE-SSW. Szczeliny w dwóch ostatnich kierunkach wpływają na podział i hydrologię tej jednostki. Według stopnia spękania i/lub postępu procesów krasowych wyróżniono dwa główne typy poziomów wodonośnych: poziom spękany (góra Essen i góra Troubia) oraz poziom porowaty (równina Hammamet).

Badanie hydrochemicznych właściwości próbek wody gruntowej wykazało, że są one zdominowane przez $\mathrm{HCO}_{3}{ }^{-} \mathrm{i} \mathrm{Ca}^{+2}$. Skład jonowy i procesy rozpuszczania/wytrącania obliczano za pomocą programu PHREEQC. $\mathrm{Na}$ skład chemiczny wody wpływają procesy rozpuszczania i precypitacji w czasie oddziaływań między wodą a podłożem skalnym oraz wymiana kationów między wodą gruntową a aluwialnymi osadami. Duże stężenie $\mathrm{CO}_{2}$ w próbkach wody sugeruje, że krąży ona w systemie otwartym. Analiza izotopowa niektórych próbek wody wykazuje ich podobieństwo do wód opadowych, co uwidacznia się w ich krótkim czasie retencji i niewielkim parowaniu wód infiltracyjnych.

Słowa kluczowe: Algieria, Hammamet, hydrogeologia, izotopy, poziom wodonośny, teledetekcja 